\title{
Summertime $\mathrm{OH}$ reactivity from a receptor coastal site in the Mediterranean Basin
}

\author{
Nora Zannoni $^{1, \text { a }}$, Valerie Gros ${ }^{1}$, Roland Sarda Esteve ${ }^{1}$, Cerise Kalogridis ${ }^{1,2}$, Vincent Michoud $^{3,4}$, Sebastien Dusanter ${ }^{3}$, \\ Stephane Sauvage $^{3}$, Nadine Locoge ${ }^{3}$, Aurelie Colomb ${ }^{5}$, and Bernard Bonsang ${ }^{1}$ \\ ${ }^{1}$ LSCE, Laboratorie Scientifique du Climat et de l'Environnement, CNRS-CEA-UVSQ, IPSL, Université Paris-Saclay, \\ 91191 Gif sur Yvette, France \\ ${ }^{2}$ Institute of Nuclear Technology and Radiation Protection, National Centre of Scientific Research "Demokritos", \\ 15310 Ag. Paraskevi, Attiki, Greece \\ ${ }^{3}$ IMT Lille Douai, Univ. Lille, SAGE - Département Sciences de l'Atmosphère et Génie de l'Environnement, \\ 59000 Lille, France \\ ${ }^{4}$ Laboratoire Interuniversitaire des Systèmes Atmosphériques (LISA), CNRS - UMR7583, Université Paris-Est-Créteil et \\ Université Paris Diderot, Institut Pierre Simon Laplace, Créteil, France \\ ${ }^{5}$ LAMP, Campus universitaire des Cezeaux, 4 Avenue Blaise Pascal, 63178 Aubiere, France \\ ${ }^{a}$ now at: Air chemistry department, Max Planck Institute for Chemistry, Mainz, Germany
}

Correspondence to: Nora Zannoni (nora.zannoni@mpic.de) and Valerie Gros (valerie.gros@1sce.ipsl.fr)

Received: 28 July 2016 - Discussion started: 4 October 2016

Revised: 3 September 2017 - Accepted: 5 September 2017 - Published: 25 October 2017

\begin{abstract}
Total hydroxyl radical $(\mathrm{OH})$ reactivity, the total loss frequency of the hydroxyl radical in ambient air, provides the total loading of $\mathrm{OH}$ reactants in air. We measured the total $\mathrm{OH}$ reactivity for the first time during summertime at a coastal receptor site located in the western Mediterranean Basin. Measurements were performed at a temporary field site located in the northern cape of Corsica (France), during summer 2013 for the project CARBOSOR (CARBOn within continental pollution plumes: SOurces and Reactivity)-ChArMEx (Chemistry and Aerosols Mediterranean Experiment). Here, we compare the measured total $\mathrm{OH}$ reactivity with the $\mathrm{OH}$ reactivity calculated from the measured reactive gases. The difference between these two parameters is termed missing $\mathrm{OH}$ reactivity, i.e., the fraction of $\mathrm{OH}$ reactivity not explained by the measured compounds. The total $\mathrm{OH}$ reactivity at the site varied between the instrumental LoD (limit of detection $=3 \mathrm{~s}^{-1}$ ) to a maximum of $17 \pm 6 \mathrm{~s}^{-1}$ (35\% uncertainty) and was $5 \pm 4 \mathrm{~s}^{-1}(1 \sigma \mathrm{SD}-$ standard deviation) on average. It varied with air temperature exhibiting a diurnal profile comparable to the reactivity calculated from the concentration of the biogenic volatile organic compounds measured at the site. For part of the campaign, $56 \%$ of $\mathrm{OH}$ reactivity was unexplained by the mea-
\end{abstract}

sured $\mathrm{OH}$ reactants (missing reactivity). We suggest that oxidation products of biogenic gas precursors were among the contributors to missing $\mathrm{OH}$ reactivity.

\section{Introduction}

Atmospheric photo-oxidation reactions are initiated by three main oxidants: the hydroxyl radical $(\mathrm{OH})$, ozone $\left(\mathrm{O}_{3}\right)$ and the nitrate radical $\left(\mathrm{NO}_{3}\right)$. Among those, the $\mathrm{OH}$ radical is by far the most important, capable of reacting with the vast majority of chemical species in the troposphere (Levy, 1971). Photooxidation reactions are the most efficient cleansing processes occurring in the atmosphere, and they constitute an important sink for reactive gases including volatile organic compounds (VOCs).

Total $\mathrm{OH}$ reactivity is the first-order total loss rate of the hydroxyl radical in the atmosphere due to reactive molecules. It is the total sink of $\mathrm{OH}$, therefore representing a top-down measure of $\mathrm{OH}$ reactants present in ambient air.

Measurements of the total loss of $\mathrm{OH}$ and $\mathrm{OH}$ reactive gases are often coupled. The total reactivity of the latter is determined by summing each gas individual reactivity as the 
product of their atmospheric concentration and their reaction rate coefficient with $\mathrm{OH}$. Here, this is referred to as calculated $\mathrm{OH}$ reactivity, and comparisons between the calculated and the measured $\mathrm{OH}$ reactivity have showed that discrepancies in various environments exist (Di Carlo et al., 2004; Nölscher et al., 2016). The missing $\mathrm{OH}$ reactivity, namely the fraction of $\mathrm{OH}$ reactivity not explained by simultaneous measurements of reactive gases, has been associated with unmeasured compounds either primary emitted, secondary generated, or both (e.g., Sinha et al., 2010; Nölscher et al., 2012a, 2013; Edwards et al., 2013; Hansen et al., 2014; Kaiser et al., 2016).

The Mediterranean Basin comprises countries from three different continents and a population of 450 million inhabitants. Its climate is characterized by humid-cool winters to hot-dry summers, when the area is usually exposed to intense solar radiation and high temperatures. Forests, woodlands and shrubs occupy large areas of the region, which has rich biodiversity and is the habitat to a high number of identified species (Cuttelod et al., 2008). The dominant airflow in summertime is driven from north to south; therefore, the basin is exposed to air masses coming from European cities and industrialized areas. Transported pollution and the intense local anthropogenic and biogenic activity result in high loadings of atmospheric gases, particles and complex chemistry (Lelieveld, 2002).

Climate model predictions indicate that the Mediterranean area will face unique impacts of climate change. Predictions show that this region will suffer higher temperatures and extended drought periods, thus affecting the strength and type of emissions which will further impact air quality and climate (Giorgi and Lionello, 2008). Finally, additional observations are useful for better predicting the future state of this region (Mellouki and Ravishankara, 2007).

In this study, we address the following scientific questions:

1. What proportion of the total reactive gases emitted and formed over the area do we know and can we detect?

2. Which species mostly influence the $\mathrm{OH}$ reactivity over this site within the basin?

To answer these questions, we measured the total $\mathrm{OH}$ reactivity at a receptor coastal site in the western Mediterranean Basin during summer 2013. Measurements were part of an intensive fieldwork campaign aimed at investigating sources and sinks of gaseous constituents in the area (CARBOSOR, CARBOn within continental pollution plumes: Sources and Reactivity, within the ChArMEx project, Chemistry and Aerosols in a Mediterranean Experiment; ChArMex, 2017, website: http://charmex.lsce.ipsl.fr/). We measured the total $\mathrm{OH}$ reactivity with the comparative reactivity method instrument (CRM) (Sinha et al., 2008) during 16 July-5 August 2013 at the monitoring station of Ersa, France. The field site was chosen for being (i) far from anthropogenic sources and (ii) exposed to aged air masses of different ori- gins, including air masses enriched in oxidation products transported from continental industrialized areas. Total $\mathrm{OH}$ reactivity here served to evaluate whether the ambient reactive gases were all identified or not. Specifically, it was useful to determine what kind of pollution event could be better captured through the instrumentation deployed at the site, assuming that a group of reactive gases traces a specific type of event (primary anthropogenic or biogenic emissions, secondary formation). Due to the high number of existing VOCs, $\mathrm{OH}$ reactivity also makes a powerful means for investigating VOC emissions and reactions. The following sections will describe the field site under study (Sect. 2), the methodologies used (Sect. 3), our results of OH reactivity (Sect. 4) and insights into the unmeasured reactive gases (Sect. 4.4).

\section{Field site}

The Ersa windfarm $\left(42.97^{\circ} \mathrm{N}, 9.38^{\circ} \mathrm{E}\right.$, altitude $\left.533 \mathrm{~m}\right)$ is located in the northern cape of Corsica (France), in the western Mediterranean Basin (Fig. 1). It is $2.5 \mathrm{~km}$ away from the nearest coast (west side) and $50 \mathrm{~km}$ away from the largest closest city and harbor Bastia (south side). It is located on a hill (533 ma.s.1.) and it is surrounded by the Mediterranean Sea on the west, north and east sides. The site is exposed to air masses from continental areas especially France and northern Italy, with the harbors of Marseille and Genoa about $300 \mathrm{~km}$ away, and the industrialized areas of Milan and the Po Valley $400 \mathrm{~km}$ away. Furthermore, the Mediterranean maquis, a shrubland biome typical of the Mediterranean region, densely surrounds the measurement station. The ground station consists of a long-term meteorology, trace gas concentrations, aerosol size and composition monitoring laboratory (measurements collected from 2012 to 2014), and temporary measurements of gases and aerosol properties over a total surface area of $\sim 100 \mathrm{~m}^{2}$ where instruments are distributed. Measurements of total $\mathrm{OH}$ reactivity and trace gases reported in this study were all performed within this area (see Fig. 1 for details).

We measured the $\mathrm{OH}$ reactivity during two main periods: an intercomparison exercise for $\mathrm{OH}$ reactivity between two CRM instruments during 8-13 July 2013 (see Zannoni et al., 2015), and the intensive ambient monitoring campaign, CARBOSOR during 16 July-5 August 2013. Within the same project, instruments for measuring radicals, inorganic and organic compounds, aerosol chemical composition and physical properties, and meteorology were simultaneously deployed. The next section will provide an overview of the methods selected for this study. 


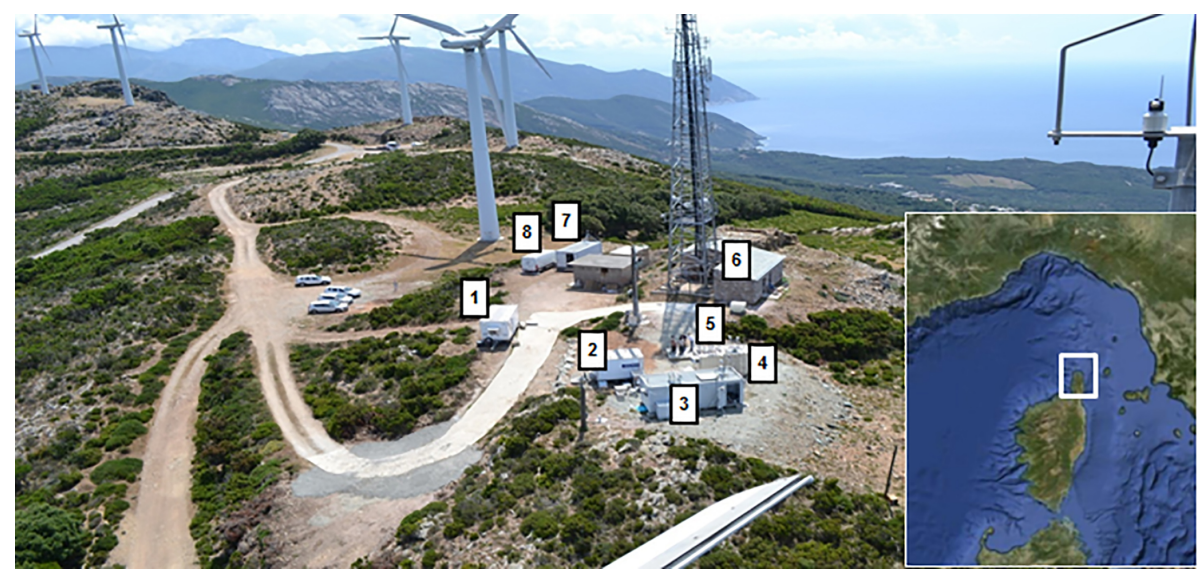

Figure 1. Field site top view, Corsica, France $\left(42.97^{\circ} \mathrm{N}, 9.38^{\circ} \mathrm{E}\right.$; altitude $\left.533 \mathrm{~m}\right)$. Measurements performed: (1) VOCs through PTR-MS and online and offline chromatography; (2) $\mathrm{OH}$ reactivity; (3) $\mathrm{NO}_{x}, \mathrm{O}_{3}$, aerosol composition and black carbon; (4) weather, and particle microphysics; (5) $\mathrm{HCHO}$, trace gases and radicals; (6) $\mathrm{CO}, \mathrm{CO}_{2}, \mathrm{CH}_{4}$; (7) trace gases and particle filters; and (8) particle physics. The photo was taken during the installation of the instruments.

\section{Methods}

\subsection{Comparative reactivity method}

We carried out measurements of total $\mathrm{OH}$ reactivity using a comparative reactivity method instrument assembled in our laboratory (CRM-LSCE from Laboratoire des Sciences du Climat et de l'Environnement; see Zannoni et al., 2015). In brief, the comparative reactivity method is based on the concept of producing a competition for in situ-generated $\mathrm{OH}$ radicals, between a reactive reference compound, in our case pyrrole $\left(\mathrm{C}_{4} \mathrm{H}_{5} \mathrm{~N}\right)$, and ambient reactive gases (Sinha et al., 2008). This is achieved by introducing a known amount of pyrrole diluted in zero air and $\mathrm{N}_{2}$ in a flow reactor coupled to a proton transfer reaction mass spectrometer (PTR-MS; see Lindinger and Jordan, 1998; De Gouw and Warneke, 2007). Pyrrole is chosen as a reference compound for its well-characterized kinetics (Atkinson et al., 1984; Dillon et al., 2012), for not being present in the atmosphere at normal conditions, and for being easily detectable at the protonated $m / z 68\left(\mathrm{C}_{4} \mathrm{H}_{5} \mathrm{NH}^{+}\right)$ through PTR-MS without any interference. The PTR-MS run at standard conditions $\left(P_{\text {drift }}=2.2 \mathrm{mbar}, E / N=130 \mathrm{Td}\right.$ $\left.\left(1 \mathrm{Td}=10^{-17} \mathrm{~V} \mathrm{~cm}^{-1}\right), \quad T_{\text {inlet }}=60^{\circ} \mathrm{C}\right)$ is the detector of choice for its real-time measurement capabilities and robustness over time (see also Nölscher et al., 2012b).

The usual CRM experimental procedure includes the following stages: monitoring of $C_{0}$ wet/dry, followed by $C_{1}$ dry or wet, $C_{2}$ wet, and $C_{3}$ ambient, with $C_{0}, C_{1}, C_{2}$, and $C_{3}$ being the concentration of pyrrole detected with the PTR-MS, in order: after injection $\left(C_{0}\right)$, after photolysis of pyrrole $\left(C_{1}\right)$, after reaction with $\mathrm{OH}\left(C_{2}\right)$, and when ambient air is injected and the competition for $\mathrm{OH}$ radicals starts $\left(C_{3}\right)$. Switches between $C_{2}$ (background pyrrole in zero air) and $C_{3}$ (pyrrole in ambient air) result in modulations of the pyrrole signal, which are used to derive total $\mathrm{OH}$ reactivity values from the following equation:

$R_{\text {air }}=\frac{\left(C_{3}-C_{2}\right)}{\left(C_{1}-C_{3}\right)} \cdot k_{\mathrm{pyrrole}+\mathrm{OH}} \cdot C_{1}$,

with $k_{\text {pyrrole }+\mathrm{OH}}$ being the rate constant of reaction between pyrrole and $\mathrm{OH}=(1.20 \pm 0.16) \times 10^{-10}$ $\mathrm{cm}^{3}$ molecule ${ }^{-1} \mathrm{~s}^{-1}$ (Atkinson et al., 1984; Dillon et al., 2012).

During the whole campaign, we ran systematic quality check controls on the instrument (see Supplement).

Sampling was performed through a $3 \mathrm{~m}$ long, $1 / 8 \mathrm{in}$. OD perfluoroalkoxy alkane (PFA) sampling line at a flow rate of $0.25 \mathrm{sL} \mathrm{min}^{-1}$ with a residence time of the sample of $3 \mathrm{~s}$. The sampling line was covered and kept at ambient temperature and installed at about $1.5 \mathrm{~m}$ above the trailer were the CRM was installed. A polytetrafluoroethylene (PFTE) filter was placed at the inlet of the sampling line to avoid sampling particles. Some highly reactive chemical species (i.e., sesquiterpenes) may have been lost before reaching the reactor due to wall losses in the sampling line and/or filter surface.

We recorded PTR-MS data using a dwell time of $20 \mathrm{~s}$ for pyrrole, with a full cycle of measurements every $30 \mathrm{~s}$. We switched between $C_{2}$ and $C_{3}$ every $5 \mathrm{~min}$, resulting in a data point of reactivity every $10 \mathrm{~min}$. Each data point of reactivity obtained from Eq. (1) was corrected for: (i) humidity changes between $C_{2}$ and $C_{3}$, (ii) deviation from the assumption of pseudo-first-order kinetics between pyrrole and $\mathrm{OH}$, and (iii) dilution of ambient air reactivity inside the reactor. A detailed description on how the correction factors were obtained and how the raw data were processed can be found in the publication of Zannoni et al. (2015). We did not account for $\mathrm{OH}$ recycling in our reactor due to nitrogen oxides $\left(\mathrm{NO}+\mathrm{NO}_{2}\right)$ since ambient nitrogen monoxide $(\mathrm{NO})$ was below $0.5 \mathrm{ppbv}$ at the site $\left(\mathrm{NO}_{2}\right.$ below $\left.2 \mathrm{ppbv}\right)$, which is too 
Table 1. Measured compounds (whose concentration was above the instrumental detection limits) and their adopted classification in the paper for calculating the $\mathrm{OH}$ reactivity. Anthropogenic VOCs, BVOCs and OVOCs stand respectively for anthropogenic, biogenic and oxygenated volatile organic compounds.

\begin{tabular}{|c|c|}
\hline Species group & Species name \\
\hline AVOCs & 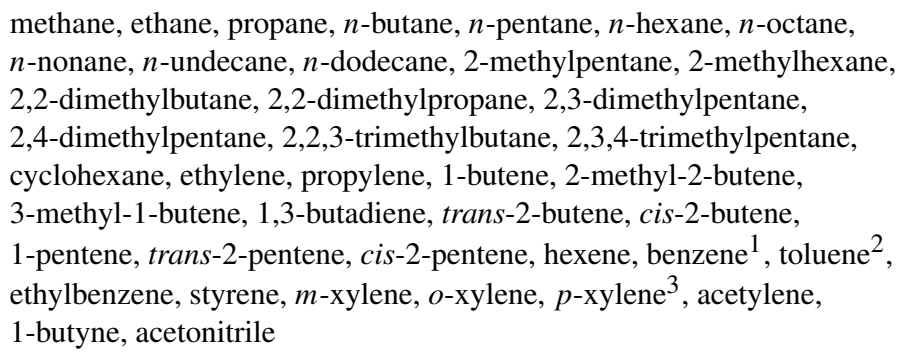 \\
\hline BVOCs & $\begin{array}{l}\text { isoprene, } \alpha \text {-pinene, } \beta \text {-pinene, D-limonene, } \alpha \text {-terpinene, } \gamma \text {-terpinene, } \\
\text { camphene }\end{array}$ \\
\hline OVOCs & $\begin{array}{l}\text { acetaldehyde }^{4}, \text { formic } \text { acid }^{5} \text {, acetone } \\
\text { methyl ethyl ketone } \\
\text { mocetic acid }\end{array}$ \\
\hline Others & $\mathrm{NO}, \mathrm{NO}_{2}, \mathrm{CO}$ \\
\hline
\end{tabular}

low for interfering with the system. Tests performed in the laboratory after the campaign have demonstrated that the instrument is not subject to ozone interference. The impact on $\mathrm{CRM}$ measurements of $\mathrm{OH}$ recycling reactions observed during the oxidation of some ambient species (e.g., methyl vinyl ketone and methacrolein - MVK + MACR; isoprene hydroxyhydroperoxides - ISOPOOHs; aldehydes) was determined to be negligible due to the low concentrations of these species and the high $\mathrm{HO}_{2}$ concentration in the CRM reactor, which disfavor unimolecular reactions.

The limit of detection (LoD) of CRM-LSCE was estimated to be $\sim 3 \mathrm{~s}^{-1}(3 \sigma)$ and the systematic uncertainty $\sim 35 \%(1 \sigma)$, including uncertainties on the rate coefficient between pyrrole and $\mathrm{OH}(8 \%)$, detector sensitivity changes and pyrrole standard concentration (22\%), correction factor for kinetics regime (26\%) and flows fluctuations (2\%); see also Michoud et al. (2015). An intercomparison exercise with another CRM instrument carried out before the campaign demonstrated that the measured reactivities were in good agreement (linear least squares fit with a slope of 1 and $R^{2}$ value of 0.75 ). An intercomparison study carried out with other instruments based on the CRM technique and on the laser-induced fluorescence-based technique showed that the measured $\mathrm{OH}$ reactivities agree with each other (Fuchs et al., 2017). The same study showed the following limitations of CRM instruments compared to laser-based techniques: (i) higher limit of detection $\left(2 \mathrm{~s}^{-1}\right.$ vs. $\left.<1 \mathrm{~s}^{-1}\right)$, lower time resolution (10-15 min vs. $30 \mathrm{~s}$ to a few minutes), lower accuracy due to the required corrections to determine the final $\mathrm{OH}$ reactivity value (pseudo-first-order deviation and $\mathrm{OH}$ recycling for environments exposed to high $\mathrm{NO}_{x}$ concentrations). Additionally, CRM instruments underestimated the measured $\mathrm{OH}$ reactivity of known terpenes mixture; therefore, if any missing reactivity is reported from terpenes-dominated environment this has to be seen as a lower limit of missing reactivity present.

\subsection{Complementary measurements at the field site}

Trace gases were measured using a broad set of techniques available at the site, including proton transfer reaction-mass spectrometry (PTR time-of-flight MS, Kore Technology Ltd., UK), online and offline gas chromatography (GC-FID/FID and GC-FID/MS, Perkin Elmer), liquid chromatography (HPLC-UV, high-performance liquid chromatography-UV light detector), the Hantzsch reaction method (Aero-Laser $\mathrm{GmbH}$, Germany) and wavelength-scanned cavity ring-down spectrometer (WS-CRDS, G2401, Picarro, USA). The measured concentration and the reaction rate coefficients of each measured compound with $\mathrm{OH}$ were used to calculate the $\mathrm{OH}$ reactivity with Eq. (2):

$R=\sum_{i} k_{i+\mathrm{OH}} \cdot X_{i}$,

with $i$ being any measured compound listed in Table 1 and $X$ its concentration. 
Table 2. Summary of the experimental methods deployed during the field campaign and needed for calculating the $\mathrm{OH}$ reactivity. The number of measured compounds includes the compounds below the instrumental detection limit (LoD).

\begin{tabular}{llr}
\hline Technique & Compounds measured & LoD (pptv) \\
\hline PTR-MS & 16 VOCs & $7-500$ \\
GC-FID/FID & 43 NMHCs $C_{2}-C_{12}$ & $10-100$ \\
GC-FID/MS & 16 NMHCs $\left(\mathrm{OVOCs}+C_{3}-C_{7}\right)$ & $5-100$ \\
Offline GC-FID/MS & $35 \mathrm{NMHCs} C_{5}-C_{16}+5$ aldehydes $C_{6}-C_{12}$ & $5-40$ \\
Hantzsch reaction & $\mathrm{HCHO}$ & 130 \\
CLD & $\mathrm{NOx}$ & 50 \\
WS-CRDS & $\mathrm{CO}_{2}, \mathrm{CH}_{4}, \mathrm{CO}$ & 1000 \\
\hline
\end{tabular}

Most of the chemical species whose reactivity was summed to determine the calculated reactivity were measured through PTR-MS and GC.

The sampling system for the PTR-MS consisted of a $5 \mathrm{~m}$ PFA sampling line, installed above the PTR-MS trailer (see Fig. 1). The residence time in the sampling line was $4 \mathrm{~s}$. We operated the PTR-MS at 1.33 mbar pressure and $40{ }^{\circ} \mathrm{C}$ temperature in the drift tube for an $E / N$ of $135 \mathrm{Td}$. The PTRMS was calibrated every 3 days using certified mixtures of different VOCs: 15 VOCs (Restek, France), 9 VOCs (Praxair, USA), and 9 oxygenated VOCs (Praxair, USA). More details on the calibration standards are available in Michoud et al. (2017). For this campaign, we only reported the masses that we clearly identified and for which we had a calibration standard. Some other masses, possibly corresponding to oxidation products of terpenes, were also extracted from the mass spectra and tentatively quantified (e.g., $m / z 99,111$, 113, 155). A visual inspection of the full mass spectra did not reveal any other abundant species that we did not consider. The GCs were calibrated twice at the beginning and at the end of the field campaign with certified gas mixtures: one including 29 VOCs (Praxair, USA) and another including 29 non-methane hydrocarbons (NMHCs) and three terpenes (NPL, UK). Total uncertainties from measurements (including precision and calibration procedure) were in the range 5-23\% for compounds measured by PTR-MS and GC-FID, and in the range $5-14 \%$ for GC-MS.

Isoprene was measured by both PTR-MS and GC and the results correlated within the measurement uncertainty (slope and $R^{2}$ of the regression for 415 data points are $0.93 \pm 0.03$ and 0.77, respectively; see Supplement). A small offset in the scatter plot (approximately $100 \mathrm{pptv}$ ) may indicate a small interference at $m / z 69$ for the PTR-MS measurements; therefore, we used data from $\mathrm{GC}$ to calculate the $\mathrm{OH}$ reactivity. We sampled individual monoterpenes with GC-FID, and on adsorbent tubes for the analysis with GC-MS, while we measured the total monoterpenes fraction by PTR-MS since the instrument cannot distinguish between structural isomers. Concentrations obtained from GC techniques were used to calculate the summed $\mathrm{OH}$ reactivity. As recently reported by Rivera-Rios et al. (2014), the $m / z 71$ measured by PTR-MS might also include the ISOPOOHs which could have formed at the site and fragmented inside the PTR-MS. However, it is important for the reader to know that we did not separate the different components of the $m / z 71$; therefore the presence of ISOPOOHs on $m / z 71$ is assumed based on the recent literature.

We refer the reader to the paper of Michoud et al. (2017) for a detailed description of the PTR-MS and online GC and offline sampling on adsorbent cartridges on GC-FID/MS deployed at the site. The formaldehyde, $\mathrm{NO}_{x}$, and $\mathrm{O}_{3}$ analyzers and WS-CRDS are briefly introduced in the following sections. Table 2 provides a summary of all techniques.

\subsubsection{Hantzsch method for measuring formaldehyde}

Formaldehyde (HCHO) was measured with a commercial instrument based on the Hantzsch reaction (model 4001, Aero-Laser GmbH, Germany). Gaseous HCHO is stripped into a slightly acidic solution, followed by reaction with the Hantzsch reagent, i.e., a diluted mixture of acetyl acetone acetic acid and ammonium acetate. This reaction produces a fluorescent compound, which absorbs photons at $510 \mathrm{~nm}$. More details are given in Dasgupta et al. (1988), Junkermann (2009) and Preunkert et al. (2013).

Sampling was conducted through a $5 \mathrm{~m}$ long PTFE $1 / 4$ in. OD line, with a $47 \mathrm{~mm}$ PFA in-line filter installed at the inlet and a flow rate of $1 \mathrm{~L} \mathrm{~min}^{-1}$.

The liquid reagents (stripping solution and Hantzsch reagent) were prepared from analytical-grade chemicals and ultrapure water according to the composition given by Nash (1953), and stored at $4{ }^{\circ} \mathrm{C}$ on the field. The instrumental background was measured twice a day (using an external hopcalite catalyst consisting of manganese and copper oxides) and calibrated three to four times a week using a liquid standard at $1.10^{-6} \mathrm{~mol} \mathrm{~L}^{-1}$, i.e., volume mixing ratio in the gaseous phase of about $16 \mathrm{ppbv}$. The calibration points were interpolated linearly in order to correct for sensitivity fluctuations of the instrument. The limit of detection was $130 \mathrm{pptv}$ $(2 \sigma)$. The coefficient of variation, i.e., the ratio of the standard deviation to the mean background value, was estimated to be $0.4 \%$. Measurements of HCHO ran smoothly from the beginning of the campaign until 11:00 LT (local time) of 


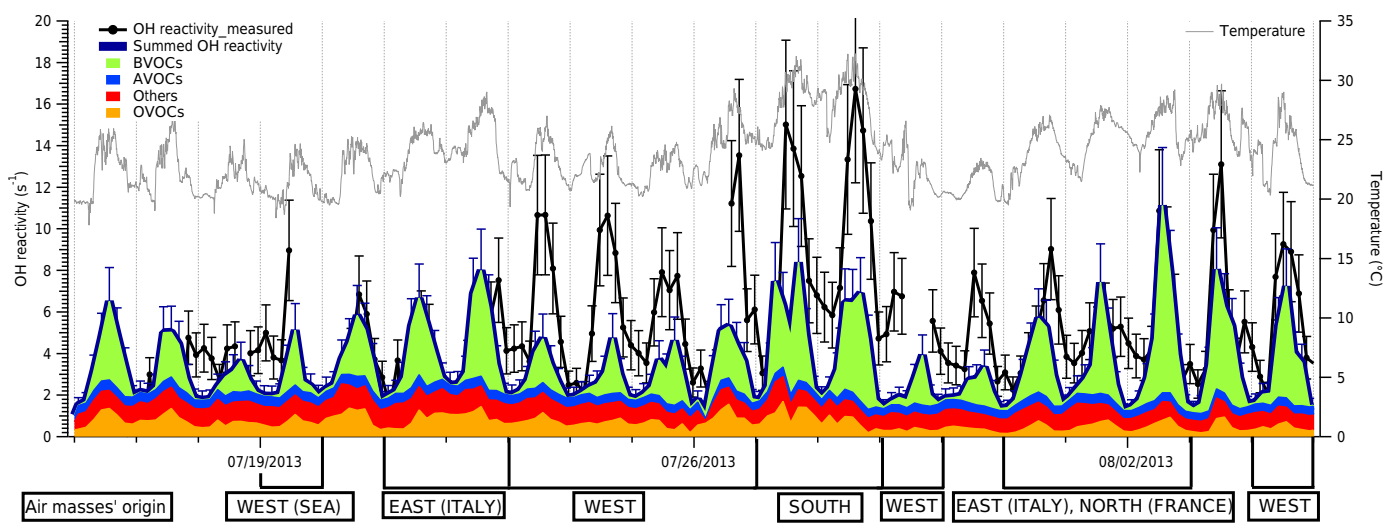

Figure 2. Three-hour averaged data of total $\mathrm{OH}$ reactivity measured and calculated from the measured gases. Summed $\mathrm{OH}$ reactivity is represented with the blue thick line and grouped as biogenic VOCs in green, anthropogenic VOCs in blue, oxygenated VOCs in orange and others in red. Others refer to carbon monoxide $(\mathrm{CO})$ and nitrogen oxides $\left(\mathrm{NO}_{x}\right)$.

28 July 2013. At this time, an instrument failure occurred and measurements were interrupted.

\subsubsection{Chemiluminescence for measuring $\mathrm{NO}_{x}$}

A CRANOX instrument (Ecophysics, Switzerland) based on ozone chemiluminescence was used to measure nitrogen oxides $\left(\mathrm{NO}_{x}=\mathrm{NO}+\mathrm{NO}_{2}\right)$. Nitric oxide is quantified directly by the instrument, while $\mathrm{NO}_{2}$ is quantified indirectly after being photolytically converted to $\mathrm{NO}$ (conversion efficiency $=86 \%$ ). The instrument consists of highperformance two-channel CLDs (chemiluminescence detectors) with pre-chamber background compensation, an integrated pump, a photolytic converter, an ozone generator and a calibrator. Control software handles and manages the different tasks. The detection limit is $50 \mathrm{pptv}(3 \sigma)$, and the time resolution is $5 \mathrm{~min}$.

\subsubsection{Wavelength-scanned cavity ring-down spectrometry (WS-CRDS) for measuring greenhouse gases}

In situ measurements of $\mathrm{CO}_{2}, \mathrm{CH}_{4}$, and $\mathrm{CO}$ molar fractions at Ersa are part of the French monitoring network of greenhouse gases, integrated in the European Research Infrastructure ICOS (Integrated Carbon Observation System). The air is sampled at the top of a $40 \mathrm{~m}$ high telecommunication tower $(573 \mathrm{~m})$ and is analyzed with a wavelength-scanned cavity ring-down spectrometer (WS-CRDS, G2401, Picarro, USA). The analyzer is calibrated every 3 weeks with a suite of four reference standard gases, whose molar fractions are linked to the WMO (World Meteorological Organization) scales through the LSCE (Laboratoire des Sciences du Climat et de l'Environnement) reference scale. Measurements were corrected for an empirical correction that takes into account the dilution effect and pressure broadening effect. A humidifying bench was developed to humidify a certified concentra- tion of a gas stream at different humidity levels (see Rella et al., 2013).

\subsection{Air masses back-trajectories}

The back-trajectories of the air masses were modeled with Hysplit (HYbrid Single-Particle Lagrangian Integrated Trajectory), developed by the National Oceanic and Atmosphere Administration (NOAA) Air Resources Laboratory (ARL) (Draxler and Hess, 1998; Stein et al., 2015), for $48 \mathrm{~h}$ every $6 \mathrm{~h}$.

The back-trajectories were grouped according to their origin, altitude and wind speed, such as (1) northeast, (2) west, (3) south, (4) northwest and (5) calm, low-windspeed/stagnant conditions. More details on the air masses origin and their photochemical age are available in Michoud et al. (2017).

\section{Results}

\subsection{Total measured $\mathrm{OH}$ reactivity}

The black line in Fig. 2 represents the $3 \mathrm{~h}$ averaged measured $\mathrm{OH}$ reactivity. Here we report all data acquired during 16 July-5 August 2013, missing data points are due to minor instrumental issues and instrumental controls. Figure 2 also shows the temperature profile of ambient air (gray line, right axis). The $\mathrm{OH}$ reactivity varied between the instrumental $\operatorname{LoD}\left(3 \mathrm{~s}^{-1}\right)$ and $17 \pm 6 \mathrm{~s}^{-1}(3 \mathrm{~h}$ averaged maximum value $\pm 35 \%$ uncertainty). From the $10 \mathrm{~min}$ time resolution data the highest value of $\mathrm{OH}$ reactivity was $22 \mathrm{~s}^{-1}$, reached on 28 July 2013 during the afternoon, when the air temperature at the site was also exhibiting its maximum. During the whole field campaign, the average measured $\mathrm{OH}$ reactivity was $5 \pm 4 \mathrm{~s}^{-1}(1 \sigma)$. This value agrees with averaged values of $\mathrm{OH}$ reactivity collected during autumn 2011 in the south of Spain for southerly marine-enriched air masses (Sinha et 


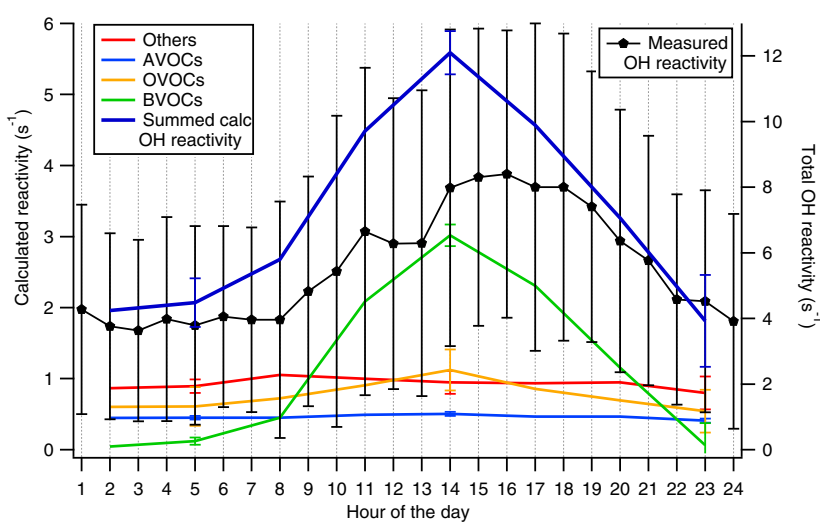

Figure 3. Diurnal patterns of measured (value with $\pm 1 \sigma$, right axis) and calculated $\mathrm{OH}$ reactivity (left axis). Others, AVOCs, OVOCs, and BVOCs are the contribution of $\mathrm{CO}$ and $\mathrm{NO}_{x}$ (others), anthropogenic volatiles, oxygenated volatiles and biogenic volatiles to the summed calculated $\mathrm{OH}$ reactivity.

al., 2012). In contrast, higher $\mathrm{OH}$ reactivity was measured during spring 2014 in a Mediterranean forest of downy oaks, where the average campaign value was $26 \pm 19 \mathrm{~s}^{-1}$ and the maximum value was $69 \mathrm{~s}^{-1}$ (Zannoni et al., 2016).

The $\mathrm{OH}$ reactivity and air temperature at the site in Corsica co-varied during the whole campaign, with highest values reached during daytime in the periods between 26 and 28 July and between 2 and 3 August. In Fig. 2 the origin of the air masses reaching the field site is also reported. The dominant origin of the sampled air masses was west, indicating air masses that had traveled over the sea being possibly more aged. It is not evident that the variability of the $\mathrm{OH}$ reactivity is affected by the origin of the air masses; in contrast, air temperature seems to have played a major role. The diurnal pattern of $\mathrm{OH}$ reactivity for the whole campaign is reported in Fig. 3. Here it is evident that the background value was about $4 \mathrm{~s}^{-1}$ during nighttime and that it increased at 08:00 LT, peaked at 11:00 LT, reached a second maximum at 16:00 LT and finally decreased at 19:00 LT, reaching its background value at 22:00 LT (local time GMT/UTC $+2 \mathrm{~h}$ ). It is worth noting that the large amplitude of standard deviation bars $(1 \sigma)$ highlights the large diel variability.

\subsection{Calculated $\mathrm{OH}$ reactivity and BVOC influence}

Table 1 provides the number and type of chemical species measured simultaneously with the $\mathrm{OH}$ reactivity. We determined the calculated $\mathrm{OH}$ reactivity from the concentrations and reaction rate coefficients with $\mathrm{OH}$ of the species reported in Table 1 using Eq. (2). Please refer to Table 2 in the Supplement for the reaction rate coefficients of the selected compounds with $\mathrm{OH}$. A broad set of compounds were monitored at the site, herein classified as anthropogenic volatile organic compounds (AVOCs, 41 compounds measured), biogenic volatile organic compounds (BVOCs, 7), oxygenated volatile
Table 3. Relative contributions of individually detected biogenic volatile organic compounds (BVOCs) to the total calculated $\mathrm{OH}$ reactivity BVOC fraction. Daytime BVOC OH reactivity accounted for a maximum value of $9 \mathrm{~s}^{-1}$, with an average of $2 \pm 2 \mathrm{~s}^{-1}$. Nighttime $\mathrm{BVOC} \mathrm{OH}$ reactivity fraction accounted for a maximum value of $0.5 \mathrm{~s}^{-1}$, with an average of $0.1 \mathrm{~s}^{-1}$.

\begin{tabular}{lrr}
\hline BVOCs & Day (\%) & Night $(\%)$ \\
\hline$\alpha$-Pinene & 7.7 & 20.7 \\
$\beta$-Pinene & 16.5 & 16.1 \\
Limonene & 12 & 11.4 \\
Camphene & 1.5 & 3.1 \\
$\alpha$-Terpinene & 31.1 & 31.3 \\
$\gamma$-Terpinene & 1.3 & 5 \\
Isoprene & 30 & 12.5 \\
\hline
\end{tabular}

organic compounds (OVOCs, 15$)$ and others ( 3 species: $\mathrm{CO}$, $\mathrm{NO}$ and $\mathrm{NO}_{2}$ ). Please note that we adopted this classification to simplify the discussion throughout the paper; for more details concerning the different sources of these compounds the reader can refer to the notes of Table 1 . Figure 2 shows the time series of the summed calculated $\mathrm{OH}$ reactivity (thick blue line) and the contributions of each class of chemicals. The maximum of the summed calculated $\mathrm{OH}$ reactivity was $11 \mathrm{~s}^{-1}$, and the $24 \mathrm{~h}$ averaged value was $3 \pm 2 \mathrm{~s}^{-1}(1 \sigma)$. As shown in Fig. 3, the class of the biogenic compounds played an important role in the daytime $\mathrm{OH}$ reactivity. Here, the shape of the diurnal pattern of the measured reactivity is slightly shifted to the BVOCs' OH reactivity, which suggests a possible influence from the oxidation products of biogenic molecules. The mean percentage contribution of each class of compounds to the summed calculated reactivity is determined for daytime (from 07:30 to 19:30 LT) and nighttime data (from 19:30 to 04:30 LT) in Fig. 4. During daytime BVOCs contributed the largest fraction of $\mathrm{OH}$ reactivity (45\%), followed by inorganic species (24\%), OVOCs (19\%) and AVOCs (12\%). Only 7 BVOCs had a higher impact than 41 AVOCs. This is explained by (i) the relatively high concentration of BVOCs (maximum values for isoprene and sum of monoterpenes is 1 and $1.5 \mathrm{ppbv}$, respectively), (ii) the generally large BVOC reaction rate coefficients with $\mathrm{OH}$ (Atkinson and Arey, 2003) and (iii) the relatively low concentration of AVOCs measured during the campaign. BVOCs accounted only for $5 \%$ of the total VOCs concentration, followed by AVOCs (15\%) and OVOCs $(79 \%)$ (mean campaign values; see also Michoud et al., 2017), which highlights the reactive nature of the measured BVOCs. During nighttime, BVOC concentrations decreased (see Figs. 2 and 3); $\mathrm{CO}$ and $\mathrm{NO}_{x}$ had the largest influence on $\mathrm{OH}$ reactivity $(43 \%)$, followed by OVOCs $(27 \%)$, AVOCs $(23 \%)$ and BVOCs (7\%). Particularly, CO and long-lived OVOCs and AVOCs constituted a background reactivity of $\sim 2-3 \mathrm{~s}^{-1}$, as also shown by the diurnal profiles reported in Fig. 3. 

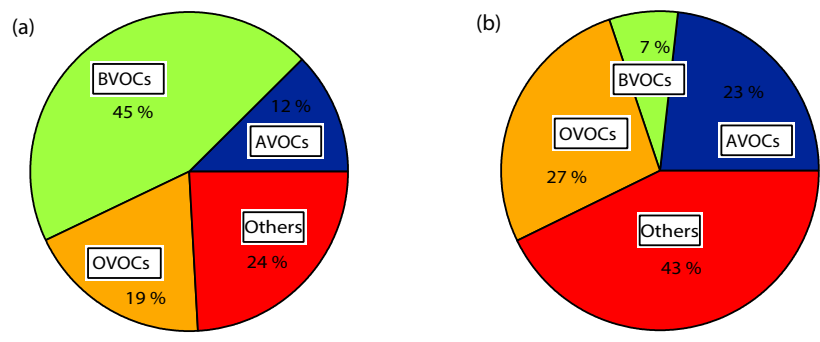

Figure 4. Daytime (a) and nighttime (b) contributions of the measured compounds to the calculated $\mathrm{OH}$ reactivity. Daytime data were collected between 07:30 and 19:30LT, while nighttime data were between 19:30 and 07:30 LT. Summed OH reactivity during daytime was maximum $11 \mathrm{~s}^{-1}$, on average $4 \pm 2 \mathrm{~s}^{-1}$, while during nighttime it was maximum $3 \mathrm{~s}^{-1}$, on average $2 \pm 0.4 \mathrm{~s}^{-1}$. Biogenic VOCs (green), AVOCs (blue), OVOCs (orange) and others (red) stand for biogenic, anthropogenic, oxygenated volatile organic compounds, and carbon monoxide and nitrogen oxides, respectively. During daytime, BVOCs, AVOCs, OVOCs and others contributions were $45,12,19,24 \%$, respectively, while they were 7 , $23,27,43 \%$, respectively during nighttime.

Within the BVOC class, the total fraction of monoterpenes contributed more than isoprene to the $\mathrm{OH}$ reactivity (Fig. 5). During daytime, $\mathrm{OH}$ reactivity due to monoterpenes was between 1.4 and $7.4 \mathrm{~s}^{-1}$ and varied with air temperature, while isoprene reactivity with $\mathrm{OH}$ varied between 0.3 and $2.3 \mathrm{~s}^{-1}$ (minimum and maximum values on 29 July and 3 August 2013, respectively). In contrast with monoterpenes $\mathrm{OH}$ reactivity, the reactivity of isoprene towards $\mathrm{OH}$ varied with both air temperature and solar irradiance. Overall, both monoterpenes and isoprene $\mathrm{OH}$ reactivities had the characteristic diurnal profile observed for their atmospheric concentrations. High concentrations depended on air temperature, solar radiation and calm, low-wind-speed conditions. These results indicate a large impact of BVOC oxidation on the local photochemistry.

The very reactive monoterpene $\alpha$-terpinene had the largest contribution on $\mathrm{OH}$ reactivity among the measured BVOCs $(31 \%)$, followed by isoprene $(30 \%), \beta$-pinene $(17 \%)$, limonene $(12 \%), \alpha$-pinene $(8 \%)$, camphene $(2 \%)$ and $\gamma$ terpinene $(1 \%)$, over a total averaged daytime reactivity due to BVOCs of $2 \pm 2 \mathrm{~s}^{-1}(1 \sigma)$ (see Table 3). During the night, monoterpenes had a larger impact than isoprene due to their known temperature dependency (Kesselmeier and Staudt, 1999). $\alpha$-Terpinene was the most reactive-to-OH BVOC also during nighttime; see Table 3 . In terms of absolute values, $\alpha$-terpinene had a maximum reactivity of $5.3 \mathrm{~s}^{-1}$ on $2 \mathrm{Au}$ gust at 14:00 LT, which is also when the maximum $\mathrm{OH}$ reactivity reported for the whole class of BVOCs occurred. The mean concentration of this compound made it the fourth most abundant BVOC measured, with isoprene being the first (35\%), followed by $\beta$-pinene (22\%), $\alpha$-pinene (15\%), $\alpha$ terpinene (13\%), limonene (9\%) and $\gamma$-terpinene (1\%). The $\alpha$-terpinene volume mixing ratio was maximum $594 \mathrm{pptv}$,

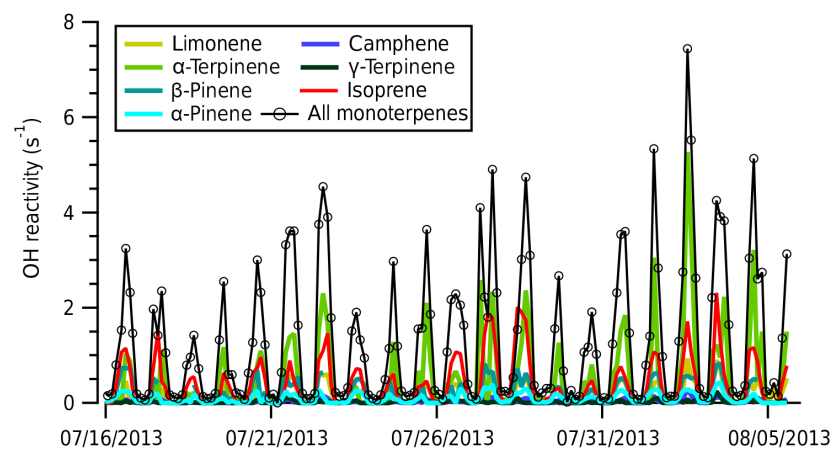

Figure 5. Absolute $\mathrm{OH}$ reactivity calculated for the measured biogenic compounds. Individual compounds' reactivities were calculated from GC measurements; "all monoterpenes" refers to the summed reactivities of the individual terpenes.

with an average value between 10:00 and 17:00 LT during the field campaign of $131 \pm 110$ pptv. Its short lifetime is due to the high reaction rate coefficient towards $\mathrm{OH}$ (as reported in the literature, i.e., $3.6 \times 10^{-10} \mathrm{~cm}^{3}$ molecule ${ }^{-1} \mathrm{~s}^{-1}$; see Atkinson, 1986, and Lee et al., 2006), which is more than 3-fold higher than the one of isoprene $\left(k_{\text {isoprene }+\mathrm{OH}}=1 \times 10^{-10} \mathrm{~cm}^{3}\right.$ molecule ${ }^{-1} \mathrm{~s}^{-1}$; Atkinson, 1986). Very little is reported in the literature regarding its emission rates and ambient levels in the Mediterranean region. Owen et al. (2001) measured $\alpha$-terpinene from a few Mediterranean tree species, including Juniperus phoenicea, Juniperus oxycedrus, Spartium junceum L., and Quercus ilex. Ormeno et al. (2007) published the $\alpha$-terpinene content as $34.9 \pm 2.3 \mu \mathrm{g} \mathrm{gDM}^{-1}$ in the leaves of Rosmarinus officinalis; shrubs of rosemary were present in large quantities around our field site in Corsica.

\subsection{Missing reactivity and air mass fingerprint}

Figure 2 reports the time series of the total measured $\mathrm{OH}$ reactivity and calculated $\mathrm{OH}$ reactivity with their associated errors (35 and $20 \%$, respectively). The largest significant discrepancy between reactivities occurred during 23-30 July (56\% of missing reactivity, calculated as the difference in percentage between measured and calculated reactivity). We combined air mass back-trajectories and atmospheric mixing ratios of some common atmospheric tracers to determine the chemical fingerprint of the sampled air and to investigate the origin of the missing reactivity. We chose isoprene and pinenes for air masses influenced by biogenic activity, while propane and $\mathrm{CO}$ were used for those enriched in anthropogenic pollutants (see Supplement). Maximum concentrations of anthropogenic pollutants were measured when the air masses originated from the northeast sector: between 21 and 23 July and between 31 July and 3 August, indicating weak pollution events coming from the industrialized areas of the Po Valley and Milan (Italy). The $\mathrm{OH}$ reactivity during these events was at most $9 \mathrm{~s}^{-1}$; no significant missing reactivity 


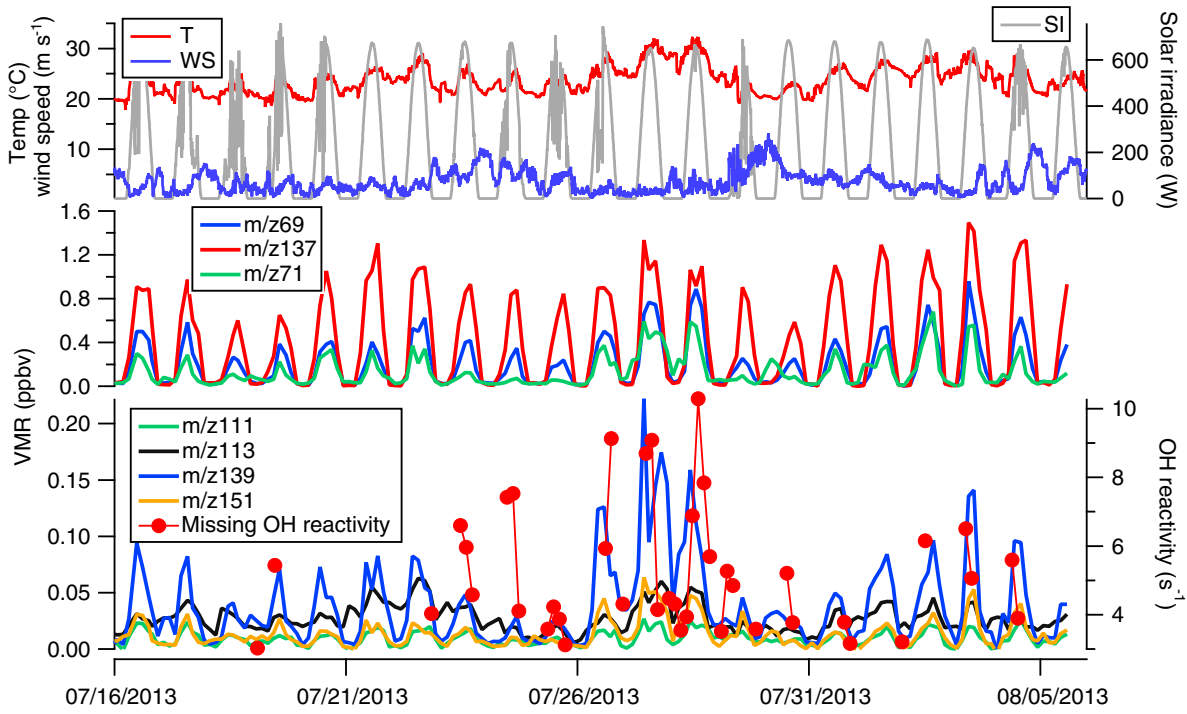

Figure 6. Volume mixing ratios (ppbv) of primary emitted and secondary produced biogenic volatile organic compounds (BVOCs) measured by PTR-MS. Primary emitted BVOCs include isoprene $(\mathrm{m} / \mathrm{z}, 69)$ and monoterpenes $(\mathrm{m} / \mathrm{z}, 137)$ (middle panel); oxidation products include methyl vinyl ketone, methacrolein, possibly isoprene hydroperoxides MVK + MACR + ISOPOOH ( $\mathrm{m} / \mathrm{z} 71)$ (middle panel), nopinone $(\mathrm{m} / \mathrm{z}, 139)$, and pinonaldehyde $(\mathrm{m} / \mathrm{z}, 151,111$ and 113) (lowest panel). Top panel provides data of temperature, wind speed and solar irradiance. The lowest panel shows the variability of the missing $\mathrm{OH}$ reactivity, calculated as the difference between measured and calculated reactivity.

occurred, mainly because of the weakness of the events, and the deployment of instruments that were able to characterize a large number of AVOCs. On the other hand, biogenic activity was independent of the wind sector and showed a larger variability linked to local drivers, such as air temperature, solar irradiance and wind speed (Fig. 6). Biogenic VOCs and their oxidation products had a large influence on the measured $\mathrm{OH}$ reactivity and potentially on the missing reactivity (Figs. 2-5); however, periods characterized by a large contribution of BVOCs to the measured OH reactivity (27-29 July and 2-4 August) present some differences in missing reactivity, which will be discussed in the next section. There is not a clear trend between the measured and missing $\mathrm{OH}$ reactivities with the origin of air masses (Fig. 2). Nevertheless, when VOCs were imported from the western sector, the air masses traveled over the sea with an average transport time of up to $48 \mathrm{~h}$, which could have favored the enrichment in oxygenated compounds through the atmospheric oxidation of primary VOCs initially present in these air masses before they left continents (Michoud et al., 2017).

\subsection{Insights into the missing $\mathrm{OH}$ reactivity}

The missing $\mathrm{OH}$ reactivity, obtained as the absolute difference between measured and calculated reactivity values, is reported in Fig. 6. Only values higher than the detection limit of $3 \mathrm{~s}^{-1}$ are displayed in this figure. Significant missing reactivity $\left(2.8 \pm 2.2 \mathrm{~s}^{-1}\right.$ on average over the whole campaign) can be observed from 23 to 29 July and more sporadically before 23 July ( 3 data points from a total of 41 ) and after 29 July (10 data points). To determine the causes of the reported missing $\mathrm{OH}$ reactivity we first investigated whether the VOC instruments deployed on the measurement site did not selectively detect some of the emitted BVOCs. We compared the total monoterpene concentration observed by PTR-MS to the summed monoterpenes concentration from GCs and calculated a concentration difference ranging from 0.2 to $0.6 \mathrm{ppbv}$ (see Supplement), the PTR-MS measurements being higher than the sum of speciated monoterpenes. Assuming a reaction rate coefficient with $\mathrm{OH}$ of $1.56 \times 10^{-10} \mathrm{~cm}^{3}$ molecule ${ }^{-1} \mathrm{~s}^{-1}$ (weighted value estimated from monoterpenes emitted by the plants present at the site; see Bracho-Nunez et al., 2011) we can roughly estimate a value of $0.8-2.3 \mathrm{~s}^{-1}$ of missing $\mathrm{OH}$ reactivity due to these unspeciated monoterpenes, which represents $30 \%$ of the reported missing reactivity on average. Therefore, unmeasured monoterpenes account for a significant fraction of the missing $\mathrm{OH}$ reactivity but do not fully explain the total missing reactivity.

The missing $\mathrm{OH}$ reactivity temperature dependency was used in previous studies (Di Carlo et al., 2004; Mao et al., 2012; Hansen et al., 2014) to determine whether terpenes (Di Carlo et al., 2004) or their oxidation products (Mao et al., 2012) could explain the missing $\mathrm{OH}$ reactivity. Terpene emissions depend on temperature following the expression, $E(T)=E(T s) \exp [\beta(T-T s)]$, where $E(T s)$ is the emission rate at temperature $T s, \beta$ a temperature sensitivity factor, and $T$ the ambient temperature. Di Carlo et al. (2004) found that the missing $\mathrm{OH}$ reactivity reported from a temperate forest in northern Michigan followed the same temperature dependency as terpene emissions, with $\beta=0.11 \mathrm{~K}^{-1}$. 
Similarly, Mao et al. (2012) reported a $\beta$ factor of $0.168 \mathrm{~K}^{-1}$ from a temperate forest in California. Since this value is higher than the upper limit of 0.144 usually observed for terpene emissions, the authors attributed the missing $\mathrm{OH}$ reactivity to unmeasured oxidation products of BVOCs, which was supported by box model simulations.

In the present study, we investigated the temperature dependency of the missing $\mathrm{OH}$ reactivity to determine whether BVOC oxidation products caused the missing reactivity for 23-26 and 27-29 July periods. We found a clear dependence $\left(\beta=0.158 \mathrm{~K}^{-1}\right.$ and $\left.R^{2}=0.643\right)$ between the missing $\mathrm{OH}$ reactivity and temperature for some days of the campaign (27-29), while no correlation $\left(\beta=0.007 \mathrm{~K}^{-1}\right.$ and $R^{2}=0.001$ ) was found during 23-26 July (see Fig. 7). The lack of a clear temperature dependency and the influence of long-range transport on air masses imported from the western sector, as demonstrated by Michoud et al. (2017), for the same data set suggest that the local oxidation of BVOCs was not the main cause of the missing reactivity observed during 23-26 July. In contrast, the similar temperature dependencies observed in the study of Mao et al. (2012) and during 27-29 July suggest that oxidation products of locally emitted BVOCs was the main cause of missing reactivity for this period. This interpretation is further confirmed by a significant increase in the concentrations of some BVOC oxidation products during 27-29 July (Fig. 6) and the accumulation of these secondary species vs. the primary biogenic compounds during nighttime (Fig. S4 in the Supplement).

Figure 6 shows the missing $\mathrm{OH}$ reactivity and volume mixing ratios of BVOCs and their oxidation products together with meteorological parameters, such as temperature, wind speed and solar irradiance. Compounds are reported using their protonated mass measured by PTR-MS, such as $m / z 69$ (isoprene) and $m / z 137$ (monoterpenes) for primary emissions, $m / z 71$ - isoprene first-generation oxidation products: methyl vinyl ketone (MVK) + methacrolein (MACR) + possibly fragments of isoprene hydroxyperoxides (ISOPOOHs) $-m / z 139$ (nopinone, $\beta$-pinene first generation oxidation product) and $m / z 151$ (fragment of pinonaldehyde, $\alpha$-pinene first-generation oxidation product) for the BVOC oxidation products. It is worth noting that $\mathrm{m} / \mathrm{z}, 111$ and 113 are also reported since these masses have been attributed to oxidation products of several terpenes. The fragments at $\mathrm{m} / \mathrm{z} 111,113$ and 151 were observed in chamber and field studies (Lee et al., 2006; Holzinger et al., 2005) as they are formed from the photo-oxidation of different terpenes; highest yields were attributed to terpenes also common to the Mediterranean ecosystem, such as myrcene, terpinolene, linalool, methyl chavicol and 3-carene (Lee et al., 2006, Bracho-Nunez et al., 2011). We note that all the abovementioned masses (with the exception of $\mathrm{m} / \mathrm{z} 111$ and 113, for which no rate coefficient was found for the reaction of the unprotonated molecule with $\mathrm{OH}$ ) have been taken into account in the calculated $\mathrm{OH}$ reactivity. The reported time series show that both primary BVOCs and most of the OVOCs

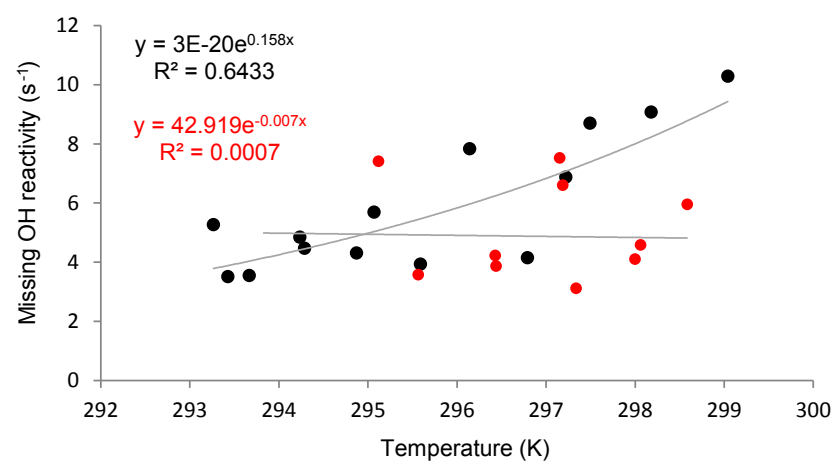

Figure 7. The temperature dependency of the difference between measured and calculated reactivity (missing $\mathrm{OH}$ reactivity) during 23-26 July (red data points) and 27-29 July (black data points). The missing reactivity is fitted to $E(T)=E(293) \exp (\beta(T-293))$. The exponential curve fits the black markers, while the close-to-straight line fits the red markers.

resulting from their oxidation had a clear diurnal profile with highest values during midday, similar to that observed for the missing reactivity.

Most of the nights were associated with low mixing ratios of BVOCs (29 pptv on average for isoprene) and their oxidation products ( $40 \mathrm{pptv}$ on average for $\mathrm{m} / \mathrm{z}, 71$ ) and corresponded to very low or no missing reactivity. Nevertheless, we note that during some nights ( 26 to 27,27 to 28,29 to 30 July), some compounds $(\mathrm{m} / \mathrm{z}, 71,113)$ were also present in low amounts and a missing reactivity of about $4 \mathrm{~s}^{-1}$ was noticed. These nights were associated with low wind speed and high temperatures, indicating a stagnant episode that could have favored the accumulation of unmeasured oxidation products during 26-29 July (ratios of $m / z, 71$ to $m / z 69$ and nopinone to $\beta$-pinene were maximum 13.9 and 7.7, respectively; see Supplement) as was already observed by night in an oak-forest canopy (Zannoni et al., 2016). The mixing ratios of the first-oxidation products of isoprene and monoterpenes $(\mathrm{m} / \mathrm{z}, 71,139)$ strongly increased after 26 July, when the wind speed was lower, and increased again after 27 July, when air temperature increased. In contrast, during another period of BVOC influence, 2-5 August, slightly lower air temperature was experienced, and less accumulation of oxidation products (Fig. S4) and lower concentrations of secondary species $(\mathrm{m} / \mathrm{z} 139,151)$ were reported (Fig. 6). These pieces of evidence also suggest that unmeasured, locally generated BVOC oxidation products contribute significantly to the missing $\mathrm{OH}$ reactivity during 27-29 July.

\section{Conclusions}

The total $\mathrm{OH}$ reactivity was used in this study to evaluate the completeness of the measurements of reactive trace gases at a coastal receptor site in the western Mediterranean Basin during 3 weeks in summer 2013 (16 July-5 August 2013). 
The $\mathrm{OH}$ reactivity had a clear diurnal profile and varied with air temperature, suggesting that biogenic compounds were significantly affecting the local atmospheric chemistry. Ancillary trace gas measurements confirmed that most of the daytime reactivity was due to biogenic VOCs, including relevant contributions from oxygenated VOCs, while during nighttime inorganic species and oxygenated VOCs exhibited the largest contribution. The $\mathrm{OH}$ reactivity was on average $5 \pm 4 \mathrm{~s}^{-1}(1 \sigma)$ with a maximum value of $17 \pm 6 \mathrm{~s}^{-1}(35 \%$ uncertainty). The observed maximum is comparable to values of $\mathrm{OH}$ reactivity measured at forested locations in northern latitudes (temperate and boreal forests as reported by Di Carlo et al., 2004; Ren et al., 2006; Sinha et al., 2010; Noelscher et al., 2013; Kumar and Sinha, 2014; Nakashima et al., 2014). This finding highlights the importance of primary emitted biogenic VOCs on the $\mathrm{OH}$ reactivity, especially where air temperature and solar radiation are high, even though our site was specifically selected for a focused study on mixed and aged continental air masses reaching the basin.

A comparison between the measured $\mathrm{OH}$ reactivity and the summed reactivity calculated from the measured species showed that on average $56 \%$ of the measured $\mathrm{OH}$ reactivity was not explained by the gas measurements during 23-29 July. During this period, the air masses came from the west (23-27 July) and the south (27-29 July); a lack of pollution events, calm wind conditions and peaks of air temperature were registered at the field site (28 July). Specifically, during 27-29 July we also detected an increase in oxygenated VOC concentrations originating from the photo-oxidation of primary emitted BVOCs, presumably due to an accumulation favored by stagnant atmospheric conditions. Highest yields of these oxidation products $(\mathrm{m} / \mathrm{z} 111,113,151)$ have been attributed to terpenes, which are strongly emitted by Mediterranean ecosystems (Lee et al., 2006; Bracho-Nunez et al., 2011). We found that the missing reactivity was temperature dependent for the same period and such dependency suggests that unmeasured oxidation products of BVOCs, as similarly reported by the study of Mao et al. (2012), caused the missing reactivity.

The impact of biogenic VOCs and their oxidation products is weaker during 23-26 July, since the site received air masses from the west and therefore from the marine sector that is less exposed to biogenic emissions. However, large values of missing $\mathrm{OH}$ reactivity were also observed, similar to those observed on 27-29 July. The lack of a temperature dependence of the missing reactivity for 23-26 suggests that species other than BVOC oxidation products locally formed were also contributing to the missing $\mathrm{OH}$ reactivity.

Mediterranean plants are known to emit large quantities of reactive BVOCs, including sesquiterpenes and oxygenated terpenes (Owen et al., 2001), which were not investigated during our fieldwork. It could be possible that these molecules, as well as their oxidation products, have also played an important role in the missing $\mathrm{OH}$ reactivity detected during the campaign.

Further studies with chemical and transport models to identify the important chemical functions of these oxygenated molecules, as well as the effects of long-range transport, would be beneficial to provide further insights.

Finally, as the Mediterranean Basin differs from side to side (air mass reception as well as type of ecosystems), more intensive studies at different key spots, e.g., western vs. eastern basin and remote vs. peri-urban ecosystems, would be helpful for a better understanding of the atmospheric processes linked to the reactive gases over the Mediterranean Basin.

Data availability. The data of $\mathrm{OH}$ reactivity and trace gases presented in this manuscript have been deposited on the Charmex database. The data are available through specific request at http://mistrals.sedoo.fr/ChArMEx/ and http://mistrals.sedoo.fr/ ?editDatsId=1420\&datsId=1420\&project_name $=$ ChArMEx .

\section{The Supplement related to this article is available online at https://doi.org/10.5194/acp-17-12645-2017- supplement.}

Competing interests. The authors declare that they have no conflict of interest.

Special issue statement. This article is part of the special issue "CHemistry and AeRosols Mediterranean EXperiments (ChArMEx) (ACP/AMT inter-journal SI)". It is not associated with a conference.

Acknowledgements. This study was supported by European Commission's 7th Framework Programmes under grant agreement number 287382 "PIMMS" and 293897 "DEFIVOC", as well as the programme ChArMEx, PRIMEQUAL CARBOSOR, CEA, CNRS and CAPA-LABEX. We would like to thank the ICOS team from LSCE for the data of CO, W. Junkermann from KIT/IMK-IFU for kindly lending the Aero-Laser instrument and Thierry Leonardis for helping with the gas measurements. A. Borbon from LISA and F. Dulac and E. Hamonou from LSCE are acknowledged for managing the CARBOSOR and ChArMEx projects. We thank the anonymous reviewers for revising the manuscript and Sabina Assan for helping with the English revision.

Edited by: William Lahoz

Reviewed by: four anonymous referees 


\section{References}

Atkinson, R.: Kinetics and mechanisms of the gas-phase reactions of the hydroxyl radical with organic compounds under atmospheric conditions, Chem. Rev., 86, 69-201, https://doi.org/10.1021/cr00071a004, 1986.

Atkinson, R. and Arey, J.: Gas-phase tropospheric chemistry of biogenic volatile organic compounds: a review, Atmos. Environ., 37, 197-219, https://doi.org/10.1016/S1352-2310(03)00391-1, 2003.

Atkinson, R., Aschmann, S. M., Winer, A. M., and Carter, W. P. L.: Rate constants for the gas phase reactions of $\mathrm{OH}$ radicals and $\mathrm{O}_{3}$ with pyrrole at $295 \pm 1 \mathrm{~K}$ and atmospheric pressure, Atmos. Environ., 18, 2105-2107, https://doi.org/10.1016/00046981(84)90196-3, 1984.

Bracho-Nunez, A., Welter, S., Staudt, M., and Kesselmeier, J.: Plant-specific volatile organic compound emission rates from young and mature leaves of Mediterranean vegetation, J. Geophys. Res.-Atmos., 116, D16304, https://doi.org/10.1029/2010JD015521, 2011.

Cappellin, L., Algarra Alarcon, A., Herdlinger-Blatt, I., Sanchez, J., Biasioli, F., Martin, S. T., Loreto, F., and McKinney, K. A.: Field observations of volatile organic compound (VOC) exchange in red oaks, Atmos. Chem. Phys., 17, 4189-4207, https://doi.org/10.5194/acp-17-4189-2017, 2017.

ChArMEx project website: http://charmex.lsce.ipsl.fr/, last access: 13 September 2017.

Cuttelod, A., García, N., Abdul Malak, D., Temple, H., and Katariya, V.: The Mediterranean: a biodiversity hotspot under threat, in: The 2008 Review of The IUCN Red List of Threatened Species, edited by: Vié, J.-C., Hilton-Taylor, C., and Stuart, S. N., IUCN Gland, Switzerland, 2008.

Dasgupta, P. K., Dong, S., Hwang, H., Yang, H.-C., and Genfa, Z.: Continuous liquid-phase fluorometry coupled to a diffusion scrubber for the real-time determination of atmospheric formaldehyde, hydrogen peroxide and sulfur dioxide, Atmos. Environ., 22, 949-963, 1988.

De Gouw, J. and Warneke, C.: Measurements of volatile organic compounds in the earth's atmosphere using proton-transferreaction mass spectrometry, Mass Spectrom. Rev., 26, 223-257, https://doi.org/10.1002/mas.20119, 2007.

Di Carlo, P., Brune, W. H., Martinez, M., Harder, H., Lesher, R., Ren, X., Thornberry, T., Carroll, M. A., Young, V., Shepson, P. B., Riemer, D., Apel, E., and Campbell, C.: Missing $\mathrm{OH}$ Reactivity in a Forest: Evidence for Unknown Reactive Biogenic VOCs, Science, 304, 722-725, https://doi.org/10.1126/science.1094392, 2004.

Dillon, T. J., Tucceri, M. E., Dulitz, K., Horowitz, A., Vereecken, L., and Crowley, J. N.: Reaction of Hydroxyl Radicals with C4H5N (Pyrrole): Temperature and Pressure Dependent Rate Coefficients, J. Phys. Chem. A, 116, 6051-6058, https://doi.org/10.1021/jp211241x, 2012.

Draxler, R. R. and Hess, G. D.: An overview of the HYSPLIT_4 modeling system of trajectories, dispersion, and deposition, Aust. Meteorol. Mag., 47, 295-308, 1998.

Edwards, P. M., Evans, M. J., Furneaux, K. L., Hopkins, J., Ingham, T., Jones, C., Lee, J. D., Lewis, A. C., Moller, S. J., Stone, D., Whalley, L. K., and Heard, D. E.: OH reactivity in a South East Asian tropical rainforest during the Oxidant and Particle Pho- tochemical Processes (OP3) project, Atmos. Chem. Phys., 13, 9497-9514, https://doi.org/10.5194/acp-13-9497-2013, 2013.

Fortems-Cheiney, A., Chevallier, F., Pison, I., Bousquet, P., Saunois, M., Szopa, S., Cressot, C., Kurosu, T. P., Chance, K., and Fried, A.: The formaldehyde budget as seen by a globalscale multi-constraint and multi-species inversion system, Atmos. Chem. Phys., 12, 6699-6721, https://doi.org/10.5194/acp12-6699-2012, 2012.

Fuchs, H., Novelli, A., Rolletter, M., Hofzumahaus, A., Pfannerstill, E. Y., Kessel, S., Edtbauer, A., Williams, J., Michoud, V., Dusanter, S., Locoge, N., Zannoni, N., Gros, V., Truong, F., SardaEsteve, R., Cryer, D. R., Brumby, C. A., Whalley, L. K., Stone, D., Seakins, P. W., Heard, D. E., Schoemaecker, C., Blocquet, M., Coudert, S., Batut, S., Fittschen, C., Thames, A. B., Brune, W. H., Ernest, C., Harder, H., Muller, J. B. A., Elste, T., Kubistin, D., Andres, S., Bohn, B., Hohaus, T., Holland, F., Li, X., Rohrer, F., Kiendler-Scharr, A., Tillmann, R., Wegener, R., Yu, Z., Zou, Q., and Wahner, A.: Comparison of $\mathrm{OH}$ reactivity measurements in the atmospheric simulation chamber SAPHIR, Atmos. Meas. Tech. Discuss., https://doi.org/10.5194/amt-2017-231, in review, 2017.

Giorgi, F. and Lionello, P.: Climate change projections for the Mediterranean region, Global Planet. Change, 63, 90-104, https://doi.org/10.1016/j.gloplacha.2007.09.005, 2008.

Hansen, R. F., Griffith, S. M., Dusanter, S., Rickly, P. S., Stevens, P. S., Bertman, S. B., Carroll, M. A., Erickson, M. H., Flynn, J. H., Grossberg, N., Jobson, B. T., Lefer, B. L., and Wallace, H. W.: Measurements of total hydroxyl radical reactivity during CABINEX 2009 - Part 1: field measurements, Atmos. Chem. Phys., 14, 2923-2937, https://doi.org/10.5194/acp14-2923-2014, 2014.

Holzinger, R., Lee, A., Paw, K. T., and Goldstein, U. A. H.: Observations of oxidation products above a forest imply biogenic emissions of very reactive compounds, Atmos. Chem. Phys., 5, 67-75, https://doi.org/10.5194/acp-5-67-2005, 2005.

Jacob, D. J., Field, B. D., Jin, E. M., Bey, I., Li, Q., Logan, J. A., Yantosca, R. M., and Singh, H. B.: Atmospheric budget of acetone, J. Geophys. Res.-Atmos., 107, ACH 5-1-ACH 5-17, 2002.

Jacob, D. J., Field, B. D., Li, Q., Blake, D. R., de Gouw, J., Warneke, C., Hansel, A., Wisthaler, A., Singh, H. B., and Guenther, A.: Global budget of methanol: Constraints from atmospheric observations, J. Geophys. Res., 110, D08303, https://doi.org/10.1029/2004JD005172, 2005.

Junkermann, W.: On the distribution of formaldehyde in the western Po-Valley, Italy, during FORMAT 2002/2003, Atmos. Chem. Phys., 9, 9187-9196, https://doi.org/10.5194/acp-9-9187-2009, 2009.

Kaiser, J., Skog, K. M., Baumann, K., Bertman, S. B., Brown, S. B., Brune, W. H., Crounse, J. D., de Gouw, J. A., Edgerton, E. S., Feiner, P. A., Goldstein, A. H., Koss, A., Misztal, P. K., Nguyen, T. B., Olson, K. F., St. Clair, J. M., Teng, A. P., Toma, S., Wennberg, P. O., Wild, R. J., Zhang, L., and Keutsch, F. N.: Speciation of OH reactivity above the canopy of an isoprene-dominated forest, Atmos. Chem. Phys., 16, 93499359, https://doi.org/10.5194/acp-16-9349-2016, 2016.

Kesselmeier, J. and Staudt, M.: Biogenic Volatile Organic Compounds (VOC): An Overview on Emission, Physiology and Ecology, J. Atmos. Chem., 33, 23-88, https://doi.org/10.1023/A:1006127516791, 1999. 
Kumar, V. and Sinha, V.: VOC-OHM: A new technique for rapid measurements of ambient total $\mathrm{OH}$ reactivity and volatile organic compounds using a single proton transfer reaction mass spectrometer, Int. J. Mass Spectrom., 374, 55-63, 2014.

Lee, A., Goldstein, A. H., Kroll, J. H., Ng, N. L., Varutbangkul, V., Flagan, R. C., and Seinfeld, J. H.: Gas-phase products and secondary aerosol yields from the photooxidation of 16 different terpenes, J. Geophys. Res., 111, D17305, https://doi.org/10.1029/2006JD007050, 2006.

Lelieveld, J.: Global Air Pollution Crossroads over the Mediterranean, Science, 298, 794-799, https://doi.org/10.1126/science.1075457, 2002.

Levy II, H.: Normal atmosphere: Large radical and formaldehyde concentrations predicted, Science, 173, 141-143, 1971.

Lindinger, W. and Jordan, A.: Proton-transfer-reaction mass spectrometry (PTR-MS): on-line monitoring of volatile organic compounds at pptv levels, Chem. Soc. Rev., 27, 347-375, https://doi.org/10.1039/A827347Z, 1998.

Mao, J., Ren, X., Zhang, L., Van Duin, D. M., Cohen, R. C., Park, J.-H., Goldstein, A. H., Paulot, F., Beaver, M. R., Crounse, J. D., Wennberg, P. O., DiGangi, J. P., Henry, S. B., Keutsch, F. N., Park, C., Schade, G. W., Wolfe, G. M., Thornton, J. A., and Brune, W. H.: Insights into hydroxyl measurements and atmospheric oxidation in a California forest, Atmos. Chem. Phys., 12, 8009-8020, https://doi.org/10.5194/acp-12-8009-2012, 2012.

Mellouki, A. and Ravishankara, A. R.: Regional Climate Variability and its Impacts in the Mediterranean Area, Springer Science \& Business Media, Springer Netherlands, 2007.

Michoud, V., Hansen, R. F., Locoge, N., Stevens, P. S., and Dusanter, S.: Detailed characterizations of the new Mines Douai comparative reactivity method instrument via laboratory experiments and modeling, Atmos. Meas. Tech., 8, 3537-3553, https://doi.org/10.5194/amt-8-3537-2015, 2015.

Michoud, V., Sciare, J., Sauvage, S., Dusanter, S., Léonardis, T., Gros, V., Kalogridis, C., Zannoni, N., Féron, A., Petit, J.-E., Crenn, V., Baisnée, D., Sarda-Estève, R., Bonnaire, N., Marchand, N., DeWitt, H. L., Pey, J., Colomb, A., Gheusi, F., Szidat, S., Stavroulas, I., Borbon, A., and Locoge, N.: Organic carbon at a remote site of the western Mediterranean Basin: sources and chemistry during the ChArMEx SOP2 field experiment, Atmos. Chem. Phys., 17, 8837-8865, https://doi.org/10.5194/acp17-8837-2017, 2017.

Millet, D. B., Guenther, A., Siegel, D. A., Nelson, N. B., Singh, H. B., de Gouw, J. A., Warneke, C., Williams, J., Eerdekens, G., Sinha, V., Karl, T., Flocke, F., Apel, E., Riemer, D. D., Palmer, P. I., and Barkley, M.: Global atmospheric budget of acetaldehyde: 3-D model analysis and constraints from in-situ and satellite observations, Atmos. Chem. Phys., 10, 3405-3425, https://doi.org/10.5194/acp-10-3405-2010, 2010.

Misztal, P. K., Hewitt, C. N., Wildt J., Blande, J. D., Eller, A. S. D., Fares, S., Gentner, D. R., Gilman, J. B., Graus, M., Greenberg, J., Guenther, A. B., Hansel, A., Harley, P., Huang, M., Jardine, K., Karl, T., Kaser, L., Keutsch, F. N., KiendlerScharr, A., Kleist, E., Lerner, B. M., Li, T., Mak, J., Nölscher, A. C., Schnitzhofer, R., Sinha, V., Thornton, B., Warneke, C., Wegener, F., Werner, C., Williams, J., Worton, D. R., Yassaa, N., and Goldstein, A. H.: Atmospheric benzenoid emissions from plants rival those from fossil fuels, Scient. Rep., 5, 12064, https://doi.org/10.1038/srep12064, 2015.
Nakashima, Y., Kato, S., Greenberg, J., Harley, P., Karl, T., Turnipseed, A., Apel, E., Guenther, A., Smith, J., and Kajii, Y.: Total $\mathrm{OH}$ reactivity measurements in ambient air in a southern Rocky mountain ponderosa pine forest during BEACHONSRM08 summer campaign, Atmos. Environ., 85, 1-8, 2014.

Nash, T.: The colorimetric estimation of formaldehyde by means of the Hantzsch reaction, Biochem. J., 55, 416-421, 1953.

Nölscher, A. C., Williams, J., Sinha, V., Custer, T., Song, W., Johnson, A. M., Axinte, R., Bozem, H., Fischer, H., Pouvesle, N., Phillips, G., Crowley, J. N., Rantala, P., Rinne, J., Kulmala, M., Gonzales, D., Valverde-Canossa, J., Vogel, A., Hoffmann, T., Ouwersloot, H. G., Vilà-Guerau de Arellano, J., and Lelieveld, J.: Summertime total $\mathrm{OH}$ reactivity measurements from boreal forest during HUMPPA-COPEC 2010, Atmos. Chem. Phys., 12, 8257-8270, https://doi.org/10.5194/acp-12-8257-2012, 2012a.

Nölscher, A. C., Sinha, V., Bockisch, S., Klüpfel, T., and Williams, J.: Total $\mathrm{OH}$ reactivity measurements using a new fast Gas Chromatographic Photo-Ionization Detector (GC-PID), Atmos. Meas. Tech., 5, 2981-2992, https://doi.org/10.5194/amt-5-2981-2012, 2012b.

Nölscher, A. C., Bourtsoukidis, E., Bonn, B., Kesselmeier, J., Lelieveld, J., and Williams, J.: Seasonal measurements of total $\mathrm{OH}$ reactivity emission rates from Norway spruce in 2011, Biogeosciences, 10, 4241-4257, https://doi.org/10.5194/bg-104241-2013, 2013.

Nölscher, A. C., Yañez-Serrano, A. M., Wolff, S., Carioca de Araujo, A., Lavrič, J. V., Kesselmeier, J., and Williams J.: Unexpected seasonality in quantity and composition of Amazon rainforest air reactivity, Nat. Commun., 7, 10383, https://doi.org/10.1038/ncomms10383, 2016.

Ormeno, E., Fernandez, C., and Mevy, J. P.: Plant coexistence alters terpene emission and content of Mediterranean species, Phytochemistry, 68, 840-852, 2007.

Owen, S. M., Boissard, C., and Hewitt, C. N.: Volatile organic compounds (VOCs) emitted from 40 Mediterranean plant species: VOC speciation and extrapolation to habitat scale, Atmos. Environ., 35, 5393-5409, https://doi.org/10.1016/S13522310(01)00302-8, 2001.

Paulot, F., Wunch, D., Crounse, J. D., Toon, G. C., Millet, D. B., DeCarlo, P. F., Vigouroux, C., Deutscher, N. M., González Abad, G., Notholt, J., Warneke, T., Hannigan, J. W., Warneke, C., de Gouw, J. A., Dunlea, E. J., De Mazière, M., Griffith, D. W. T., Bernath, P., Jimenez, J. L., and Wennberg, P. O.: Importance of secondary sources in the atmospheric budgets of formic and acetic acids, Atmos. Chem. Phys., 11, 1989-2013, https://doi.org/10.5194/acp-11-1989-2011, 2011.

Preunkert, S., Legrand, M., Pépy, G., Gallée, H., Jones, A., and Jourdain, B.: The atmospheric HCHO budget at Dumont d'Urville (East Antarctica): Contribution of photochemical gasphase production versus snow emissions, J. Geophys. Res.Atmos., 118, 13319-13337, 2013.

Rella, C. W., Chen, H., Andrews, A. E., Filges, A., Gerbig, C., Hatakka, J., Karion, A., Miles, N. L., Richardson, S. J., Steinbacher, M., Sweeney, C., Wastine, B., and Zellweger, C.: High accuracy measurements of dry mole fractions of carbon dioxide and methane in humid air, Atmos. Meas. Tech., 6, 837-860, https://doi.org/10.5194/amt-6-837-2013, 2013.

Ren, X., Brune, W. H., Oliger, A., Metcalf, A. R., Simpas, J. B., Shirley, T., Schwab, J. J., Bai, C., Roychowdhury, U., Li, 
Y., Cai, C., Demerjian, K. L., He, Y., Zhou, X., Gao, H., and Hou, J.: $\mathrm{OH}, \mathrm{HO}_{2}$, and $\mathrm{OH}$ reactivity during the PMTACSNY Whiteface Mountain 2002 campaign: Observations and model comparison, J. Geophys. Res.-Atmos., 111, D10S03, https://doi.org/10.1029/2005JD006126, 2006.

Rivera-Rios, J. C., Nguyen, T. B., Crounse, J. D., Jud, W., St. Clair, J. M., Mikoviny, T., Gilman, J. B., Lerner, B. M., Kaiser, J. B., de Gouw, J., Wisthaler, A., Hansel, A., Wennberg, P. O., Seinfeld, J. H., and Keutsch, F. N.: Conversion of hydroperoxides to carbonyls in field and laboratory instrumentation: Observational bias in diagnosing pristine versus anthropogenically controlled atmospheric chemistry, Geophys. Res. Lett., 41, GL061919, https://doi.org/10.1002/2014GL061919, 2014.

Sinha, V., Williams, J., Crowley, J. N., and Lelieveld, J.: The Comparative Reactivity Method - a new tool to measure total $\mathrm{OH}$ Reactivity in ambient air, Atmos. Chem. Phys., 8, 2213-2227, https://doi.org/10.5194/acp-8-2213-2008, 2008.

Sinha, V., Williams, J., Lelieveld, J., Ruuskanen, T. M., Kajos, M. K., Patokoski, J., Hellen, H., Hakola, H., Mogensen, D., Boy, M., Rinne, J., and Kulmala, M.: OH Reactivity Measurements within a Boreal Forest: Evidence for Unknown Reactive Emissions, Environ. Sci. Technol., 44, 6614-6620, https://doi.org/10.1021/es101780b, 2010.

Sinha, V., Williams, J., Diesch, J. M., Drewnick, F., Martinez, M., Harder, H., Regelin, E., Kubistin, D., Bozem, H., HosaynaliBeygi, Z., Fischer, H., Andres-Hernandez, M. D., Kartal, D., Adame, J. A., and Lelieveld, J.: Constraints on instantaneous ozone production rates and regimes during DOMINO derived using in-situ $\mathrm{OH}$ reactivity measurements, Atmos. Chem. Phys., 12, 7269-7283, https://doi.org/10.5194/acp-127269-2012, 2012.
Stein, A. F., Draxler, R. R., Rolph, G. D., Stunder, B. J. B., Cohen, M. D., and Ngan, F.: NOAA's HYSPLIT atmospheric transport and dispersion modeling system, B. Ame. Meteorol. Soc., 96, 2059-2077, https://doi.org/10.1175/BAMS-D-14$00110.1,2015$.

Yáñez-Serrano, A. M., Nölscher, A. C., Bourtsoukidis, E., Derstroff, B., Zannoni, N., Gros, V., Lanza, M., Brito, J., Noe, S. M., House, E., Hewitt, C. N., Langford, B., Nemitz, E., Behrendt, T., Williams, J., Artaxo, P., Andreae, M. O., and Kesselmeier, J.: Atmospheric mixing ratios of methyl ethyl ketone (2-butanone) in tropical, boreal, temperate and marine environments, Atmos. Chem. Phys., 16, 10965-10984, https://doi.org/10.5194/acp-1610965-2016, 2016.

Zannoni, N., Dusanter, S., Gros, V., Sarda Esteve, R., Michoud, V., Sinha, V., Locoge, N., and Bonsang, B.: Intercomparison of two comparative reactivity method instruments inf the Mediterranean basin during summer 2013, Atmos. Meas. Tech., 8, 3851-3865, https://doi.org/10.5194/amt-8-3851-2015, 2015.

Zannoni, N., Gros, V., Lanza, M., Sarda, R., Bonsang, B., Kalogridis, C., Preunkert, S., Legrand, M., Jambert, C., Boissard, C., and Lathiere, J.: OH reactivity and concentrations of biogenic volatile organic compounds in a Mediterranean forest of downy oak trees, Atmos. Chem. Phys., 16, 1619-1636, https://doi.org/10.5194/acp-16-1619-2016, 2016. 